that it gets thoroughly into the center of each pigment spot. The application is practically painless, and the consequent bubbling removes the inorganic remains of the powder. I have found it necessary to prick each point thoroughly open, and have used the solution of U. S. P. strength with perfect results, absolutely no pigment remaining. Very truly,

C. H. Browning, M. D.

\section{Pathologic Exhibit for A. M. A.}

Louisvilite, Ky., Dec. 28, 1899.

To the Editor: It gave me great pleasure to read in the Journal of Dec. 2, 1899 (see Journar, December 16, p. 1564, December 23, p. 1630) a letter from Dr. Frank B. Wynn, rerelating to a section on pathology in the Association. No one feature could be of more interest than this. It encourages study in this special department, and by an exhibit profits the whole profession.

The Indiana State Medical Society deserves great credit for starting this project, and the display last June was of great interest to all of us. I hope, therefore, that the suggestion of Dr. Wynn will be carefully considered, and that each state society may follow in this very worthy undertaking.

$$
\text { Respectfully, }
$$

JosePh M. MAThews, M.D

\section{Association $\mathcal{L}$ (ews.}

Competition for the American Medical Association Medal.-At the meeting of the American Medical AssociaTION, held June 4, 1897, it was resolved to restore the former policy of the Association in favor of offering annually a gold medal for meritorious scientific work. The committee for this year, consisting of Drs. George M. Gould of Philadelphia, E. Fletcher Ingals of Chicago and $T$. W. Huntington of Sacramento, Cal., desires to direct attention to the following rules governing the competition:

1. The medal shall contain the seal of the United States or a seal of the Association, to be hereafter designed, on one side and an Esculapian staff on the other, together with the name of the recipient of the medal and suitable inscriptions.

2 . The commercial value of the medal shall be $\$ 100$.

3. A standing committee on prize medals, consisting of three members of the Association, shall be elected by the Business Committee as follows: One for one year, one for two years and one for three years, and thereafter one to be elected yearly to hold office until in either case his suceessor has been duly elected. In no ease shall a member of the Business Committee hold a place on the Committee on Prize Medals.

4. The competing essays shall be typewritten or printed and shall bear no mark revealing their authorship; but instead of the name of the author, there shall appear on each essay a motto, and accompanying each essay shall be a sealed envelope containing the name of the author and bearing on its outer surface the motto of identification. No envelope is to be opened by the Committee until a decision has been reached as to the most deserving essay, and the other essays have been returned to their respective owners. The Committee shall have authority to reject and return all essays in case none have been found worthy of the Association medal. Competing essays must be in the hands of the Committee not later than March 1, 1900. For further information address any member thereof.

\section{Book 2rotices.}

The Cranial and Finst Spinal Nerves of Menidia.-A Contribution on the Nerve Components of the Bony Fishes. With Seven Plates. By C. Judson Herrick, Associate in Comparative Neurology, Pathological Institute of the New York State Hospitals. State Hospital Press, Utica, N. Y., 1899. This monographic work, which has appeared simultaneously in the latest issues of the Archives of Neurology and Psychiatry, and the Journal of Comparative Neurology, is a study of the cerebral developments of one of the lower vertebrates.
Its interest to physicians and medical students is in the light it, with other similar investigations, throws on the origin and development of the like organs in the higher vertebrates and in man, and it is only within the aid of such researches that we can properly understand the questions that arise especially in relation to the brain and nervous system in medicine and in human anatomy and physiology. The broad culture that a medical teacher or investigator should possess necessarily requires a knowledge of comparative anatomy, the more thorcugh the better. In neurology this is perhaps more obviously true than in other special departments, but it is true in all. The study of evolution is, as Herrick points out, a usetul supplement to the study of pathology, showing, as it were, an experiment of Nature carried out in detail over an indefinite period of time, as compared with the rapid course, and our consequent lack of ready grasp of processes of disease. The utility of such works as these to the medical man is therefore obvious, though it may not be every practitioner who can command the time for their thorough study. To the working neurologist some acquaintance with them ought to be indispensable. This study was awarded the Cartwright prize for 1899, by the Alumni Association of the College of Physicians and Surgeons, Columbia Liniversity, New York.

Text-Book of the FMbryology of Invertebrates. By E. Korschelt, Professor of Zoölogy and Comparative Anatomy in the University of Berlin. Vol. I: Porifera, Cnidaria, Ctenophora, Vermes, Enteropneusta, Echinodermata. Translated from the German by Edward L. Mark, Ph.D., Hersey Professor of Anatomy in Harvard University, and W. McM. Woodsworth, Ph.D., Instructor in Microscopical Anatomy in Harvard University. Vol. II: Phoronidea, Bryozoa, Ectoprocta, Brachiopoda, Entoprocta, Crustacea, Palæostraca. Vol. III: Arachnida, Pentastomidæ, Pantopoda, Tardigrada, Onychophora, Myriopoda, Insecta. Translated from the German by Matilda Bernard. Revised and edited with additional notes by Martin F. Woodward, Demonstrator of Zoölogy, Royal College of Science, London. London: Swan, Sonnenschein \& Co., Ltd. New York: The MacMillan Co. 1899.

This translation of a leading German work on embryology will be welcomed by English-speaking ' : ologists, and while it is not exactly in the dire ne medical study, it should be also valuable to a large section of our profession. Comparative embryology, even more than some other departments of zoölogic study, is a close collateral ti unedicine, and no physician will be the worse for an acquaintance with this subject. The three volumes here presented give one of the most complete, available presentations of the subject in our language, and with the coming fourth volume, which will probably soon appear, will form a standard authority covering the whole ground of invertebrate embryology.

The translators and editors, both American and English, have done their work well, and their additions bring the subject up to our present knowledge. One can not but regret, however, that it was ever originally written in German. The controversy as to the signification of the word Anlage is familiar to all readers of recent English and American scientific literature, and here we have it translated by different words in the first, and second and third volumes, respectively. As the editors call special attention to this fact, and to other terms loosely employed by the Germans, no harm is done, but it would have been better for scientific purposes had the original language been as definite and exact as some others.

Each volume has its own index, and is complete in itself. The work as a whole, as far as translated, is a most valuable addi. tion to morphologic literature in our language, and one that we trust will have the reception it deserves.

Bacteria: Especially As They Are Reia ted to the Economy of Nature, to Industrial Proresses and to the Public Health. By George Newman, M.D., F.R.S. (Edin.), D.P.H. (Camb.), Etc. Demonstrator of Bacteriology in King's College, London. Illustrated. New York: G. P. Putnam's Sons. 1899.

This rolume in the Science Series published by Putnam's Sons in New York and Murray in London, gives a very excellent popular statement of the present state of our knowledge re- 